\title{
Globalization and Deindustrialization: The Political-Economy of Domestic Institutions (or Lack Thereof) in the Post-New Order Indonesia
}

\author{
Rakhmat Syarip \\ Universitas Indonesia
}

\begin{abstract}
This paper discusses determining factors behind Indonesia's deindustrialization in the post-New Order era. Over time, manufacturing sector shows decreasing contribution to Indonesia's GDP, while industrial transformation stagnates with limited high-technology exports. Using Linda Weiss' (1998) Governed Interdependence and Christopher Dent's (2003) Adaptive Partnership theories, this paper offers political-economy arguments to explain the phenomenon. Internationally speaking, while it is true that neoliberal globalization imposes some restrictions, it is too much to claim the death of industrial policy. Rather, it is the limitation of domestic institutions that is best explained Indonesia's case. Using automotive, rattan and copper industries as case studies, the argument consists of two parts. First, in post-New Order Indonesia there is insufficient coordination between state and capital (both foreign and domestic). Second, the state in Indonesia lacks sufficient administrative capacity. The paper recommends Indonesia to invest in domestic institution as a means to reindustrialize.
\end{abstract}

Keywords: deindustrialization, globalization, domestic institutions, state-business coordination, state's administrative capacity

Tulisan ini membahas tentang faktor-faktor penyebab terjadinya deindustrialisasi di Indonesia pasca Orde Baru. Kontribusi sektor manufaktur Indonesia terhadap PDB terus menurun, sementara transformasi industri mengalami stagnasi dengan minimnya ekspor produk berteknologi tinggi. Dengan menggunakan teori Governed Interdependence dari Linda Weiss (1998) dan Adaptive Partnership dari Christopher Dent (2003), tulisan ini memberikan argumen ekonomi-politik untuk menjelaskan fenomena tersebut. Dari sisi internasional, meskipun globalisasi neoliberal membatasi pengambilan kebijakan industri, peluang untuk melaksanakan kebijakan tersebut tidaklah mati. Dengan demikian, faktor domestik, khususnya kelemahan institusi domestik, menjadi penyebab utama terjadinya deindustrialisasi di Indonesia. Dengan menggunakan industri otomotif, rotan, dan pengolahan tembaga sebagai studi kasus, tulisan ini berisikan dua buah argumen. Pertama, Indonesia pasca Orde Baru tidak memiliki hubungan koordinatif yang memadai antara negara, pemilik modal asing, dan domestik. Kedua, negara di Indonesia tidak memiliki kapasitas administratif yang mumpuni. Sebagai rekomendasi, Indonesia perlu untuk berinvestasi di bidang institusi domestik untuk memacu reindustrialisasi.

Kata-kata kunci: deindustrialisasi, globalisasi, institusi domestik, koordinasi negaraswasta, kapasitas administratif negara 
The industrial sector in Indonesia has performed poorly in the post-New Order era. Over the years, the manufacturing sector has shown decreasing contribution to Gross Domestic Product (GDP): 28.34 percent in 2004, 21.03 percent in 2013 and 20.84 percent in 2015 (sindonews.com, 20 September 2016). Manufacturing sector also has grown slower than overall economic growth. It only grew 4.37 percent and 4.61 percent in 2013 and 2014, whereas national economy grew 5.78 percent (2013) and 5.02 percent (2014) (beritasatu.com, n.d.). Such performance is worse than in the New Order era, where manufacturing sector grew as high as 11 percent in the 1990 (beritasatu.com, n.d.). Deindustrialization symptoms are also observable in industrial transformation. Athukorala (2006) shows that Indonesia's export after the New Order era still consists of primary and labor-intensive sectors, such as natural resources (31.1 percent), resoucebased manufacturers (21.5 percent) and apparel \& footwear products (18.1 percent). Molnar and Lesher (2008) also show that Indonesia's high technology product only constituted less than 10 percent of overall export, while China reached 35 percent. Moreover in 2010-2011, Indonesia's parts and components export in electrical machinery only constituted 3 percent of total export (Yamashita, 2015, 28). Meanwhile, Singapore, Malaysia and the Philippines exceeded Indonesia with 19 percent, 21 percent and 30 percent (Yamashita, 2015, 28). ${ }^{1}$

This paper argues that such deindustrialization is caused by weak domestic institutions. Based on East Asian economic miracle, Weiss (1998) and Dent (2003) argue that a conducive domestic institutions is important to capture opportunities and to mitigate challenges offered by economic globalization and to transform them into industrialization. In Indonesia, however, the situation is vice versa. On one hand, Indonesia lacks coordination between state and capital (foreign and domestic). On the other hand, state in Indonesian lacks the necessary administrative capacity to guide industrial transformation.

The organization of this paper is as follows. After the introduction part, this paper discusses the theoretical framework. Section III discusses the feasibility of conducting industrial transformation in the globalization era. Section IV and V discuss main arguments, namely the lack of state-business coordination and administrative state. The writing ends with conclusion and recommendation.

\section{East Asian Experience: Institutional Design for Industrial Transformation}

This paper adopts Transformationalist School on Globalization. According to David Held, et.al. (1999), globalization nowadays is both a 'shake-out' and a 'powerful transformative force' that changes politics, economics and socio-cultural sphere. This school of thought rejects Hyperglobalist ideas that the 'global' triumphs over 'national' and that the state is no longer relevant as globalization creates borderless world, global market and global civilization. Transformationalist also rejects Sceptist camp which stresses that, rather than globalization, what happens nowadays is a mere 'internationalization' in which national economies interact with each other and that the state is its driving force. Rather, Transformationalist acknowledges the 'new sovereignty regime' where state and nonstate actors coexist and exert their influences over one another. Transnationalism appears as state alone cannot address global issues, such as exchange of goods and finance or climate change, and needs cooperation with other actors. Therefore, the role of the state is reconstituted; it is neither strengthened nor weakened, for it adapts to current global phenomenon. In economic globalization, the state must collaborate with transnational foreign and domestic capital.

\footnotetext{
${ }^{1}$ Parts and components production is a more technologically-intensive process than assembling. The higher the export share, the more integrated a country is with the global production network.
} 
In East Asia, there is a considerable body of literature to explain industrial transformation. Economic miracle is possible because of East Asian countries' strategy to deal with globalization. Linda Weiss (1998) offers the theory of Governed Interdependence (GI) as an extension of the classical concept of Developmental State (Johnson, 1982) and Governed Market (Wade, 1990). ${ }^{2}$ If these scholars emphasize stateguided planning and state's "power 'over' society" to implement it, Weiss (1998) puts forward the idea of "power 'through' society", in which state collaborates with business sectors to determine the direction of industrial transformation. Similarly, Dent's (2003) work on "Adaptive Partnership" also acknowledges the central role of coordination between state, foreign and domestic capital to achieve common foreign economic policies (Figure I). Both theories acknowledge that such collaboration is essential to formulate the best intervention strategy to achieve common goals, namely industrial transformation in the globalization era.

\section{Figure I - Actors in Industrial Transformation}

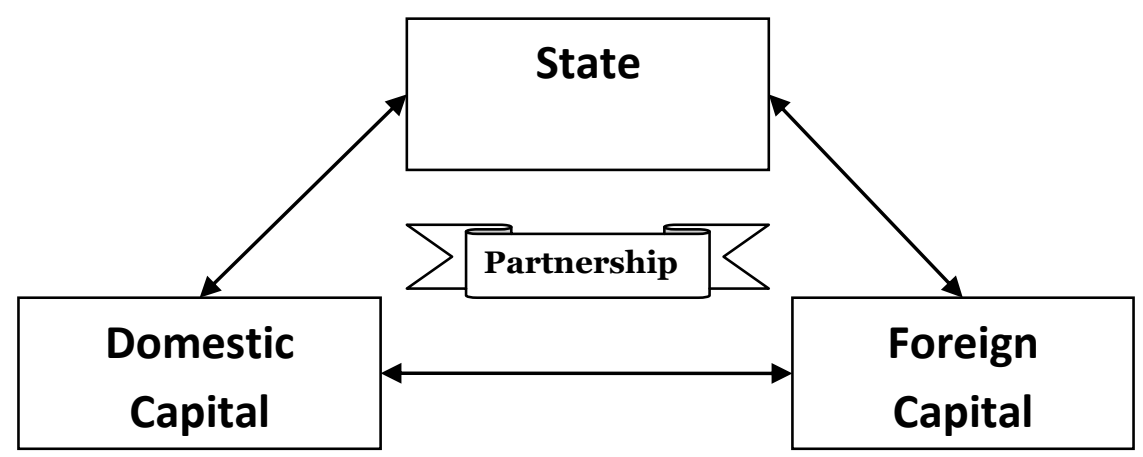

Both Weiss (1998) and Dent (2003) focus on the role of domestic institutional design (Figure II). Institution refers to rules, norms, decision-making procedures and other attributes, both formal and informal, that govern political and economic relations among actors at domestic setting. First, there should be coordinative state-business relations. Industrial transformation cannot materialize unless all actors, in this case the state, domestic and foreign capital, recognize that they share similar interest of achieving it. Egoism and short-term gains can bring detrimental result to this long-term goal. Institutionalized channels of communication should also be available; in Japan, there are more than 200 deliberative councils, while in South Korea, numerous monthly export promotion meetings between high-ranking state officials and business group are available. Business sector should also possess a cohesive, rather than fragmented, association as an arena to articulate and aggregate interests as well as to distribute information and to coordinate policy. Weiss (1998) argues that such institutional design is critical to explain Taiwan's decision to focus on high-quality, design-specific textile products against cheap, low-quality products from Southeast Asia. Dent (2003) also shows Singapore's decision to be the center of excellence in biotechnology, research and development (R\&D) and regional headquarters was made up from the abovementioned

\footnotetext{
${ }^{2}$ Johnson (1982) and Wade (1990) reject neoclassical economist argument as both of them believe that liberalization, high level of investment and outward-oriented strategy are not enough to explain the success of East Asia. Rather, they argue that state's adaptation to economic openness is more important. While liberalizing some sectors, state also employs strategic industrial policy to some other sectors to reach global competitiveness. Market is intentionally distorted through temporary subsidy, tariff and other supports to nurture infant domestic industries. State has strong capability (and credibility) through meritocratic recruitment, controls over financing and state-of-the-art planning and implementing function.
} 
domestic institutions. Second, there should be a sound state's administrative capacity. State should possess technocratic capacity to plan and execute policy, stemming from meritocratic recruitment and high-quality business-intelligence function. State should also embody 'embedded autonomy' structure within society, where the former is sufficiently insular to resist the latter's pressure for short-term economic gains, but is sufficiently embedded so that it can gather factual data for planning, monitoring and evaluation purposes. State should also be able to provide performance-based support, in which business must meet some performance requirements before accessing subsidy, loan, R\&D funding and other assistances. Support is temporary rather than prolonged; as entrepreneur gradually improves its international competitiveness, state gradually reduces its support.

\section{Figure II - Theoretical Framework}

\section{Coordinative State-Business \\ Relations \\ - Industrial transformation as a common interest of state, foreign and domestic capital \\ - Institutionalized channels for intensive communication \\ - Cohesive business association}

\section{Sound State's Administrative} Capacity

- Technocratic capacity: planning and implementation function

- Embedded autonomy structure

- Performance-based supports
Industrial

Transformation in the Globalization Era

\section{Question of Policy Space: Is Industrial Policy Still Feasible in the Globalization Era?}

Hyperglobalist likes to portray that it is now the end of strategic industrial policy. The school argues that global competition creates such disciplinary mechanism that state has no option than to follow neoliberal policy. The argument is not without merit. Global regime such as the World Trade Organization (WTO) has created various market-based regulations to limit state intervention. WTO's basic mandate is to allow reciprocal market access through agreed tariff and non-tariff reduction at non-discriminatory basis. ${ }^{3}$ WTO also regulates the Trade-Related Investment Measures (TRIMs) which restricts any performance-related measures, such as local-content or export requirement. ${ }^{4}$ Moreover, the proliferation of free trade agreements (FTAs) makes state commit more tariff and

\footnotetext{
${ }^{3}$ Under this rule, selective liberalization a la East Asia is no longer possible.

${ }^{4}$ Local content requirement is a policy to make sure a foreign company buys components (say, 40\%) from local, rather than foreign suppliers. Export requirement regulates foreign and domestic firms to export some percentage of their production, rather than to fully channel them to domestic market. Both policies are part of strategic industrial policy. They specifically aim to balance foreign exchange demand, to develop domestic supporting industry and to expose companies to international competition.
} 
non-tariff reduction at more sectors than the WTO commitment. ${ }^{5}$ Liberalization of capital market also makes countries prone to speculative activity and global financial instability. Therefore, Hyperglobalist claims that globalization spells the end of state intervention policy.

However, many scholars argue that industrial policy remains in practice today. While it is true that many policy measures are no longer feasible, there are still plenty rooms to maneuver if state commits to industrialization (Noland and Pack, 2003, 88). In WTO, although subsidy for export is forbidden, the rule allows subsidies for university-based or national laboratory-based research, precompetitive development, or promoting underdeveloped local areas (Noland and Pack, 2003). Even though the TRIMs does not recognize performance requirement, there is no penalty if a state directs support for cost reduction purpose (Noland and Pack, 2003). Even more, many countries still commit to provide generous loans to specific industrial sectors, such as India in textile and motion picture industries, Malaysia in maritime-related industry and China in software and information industries (Rodrik, 2007). Some states support their small and medium enterprises (SMEs) to link with global production network while some others invest in skilled and trained human resources (Held, et.al, 1999). Therefore, it is state's adaptation, rather than state retreat, that is under way in globalization. The key to promote industrial development in the globalization era is to identify 'loopholes' within the global regime and to seek feasible policy supports.

Moreover, Rodrik (2007) argues that developing countries must push for policy space in international negotiation. Tunisia and Morocco were able to maintain custom duties for specific infant industries in their FTAs with the European Union (EU). In East Asia, some countries were able to generate development aid from an Economic Partnership Agreement (EPA) with Japan. Solis (2009) shows that EPA (basically an FTA with economic package) enables Indonesia, Malaysia and the Philippines to get technology or technical skills support. Meanwhile, ASEAN FTA (AFTA) provides sufficiently flexible measures for industrial policy. Malaysia has used it to delay tariff liberalization in automotive sector from 2000 to 2005 (Nesadurai, 2003).

\section{Domestic Approach: Lack of Coordinative State-Business Relations}

Despite many possibilities at the international level, Indonesia still performs poorly at the domestic arena. In fact, deindustrialization happens not because of restrictive international environment, but the weakness of domestic institutions. Industrial sectors in Indonesia are not lacking examples of poor coordination among state, domestic and foreign capital. Auto-parts sector is a good case study. Indonesia is known to be an assembling center for Japanese automotive company. Such industry utilizes low technology and high number of low-skilled labors. Development of auto-part industry is prerequisite for Indonesia to move up the value chain; producing parts and components requires higher degree of technology and skills. Under the Decree of Ministry of Industry No. 307/ 1976, the government imposed local-content requirement policy to stimulate domestic and foreign players to produce auto-parts (Thee, 2012, 275). Starting in 1999, the government switched to "Harmonized System" which liberalized auto-part industry as part of Indonesia's compliance to the WTO rule (Thee, 2012, 275). However, both policies did not lead to desirable result. In 2006, while Thailand and Singapore produced 1.03 percent and 0.61 percent of world production, Indonesia's performance was poor at 0.37 percent (Johnson, 2007 in Thee, 2012, 275). Indonesia's auto-parts industry also does not have sufficient skills and technology, remain domestic-oriented and have minimum linkage to regional production network (Thee, 2012). Parts and components

5 Some FTAs, such as United States-based bilateral FTA, entails WTO-plus liberalization scheme, such as guarantee to profit repatriation and restriction to technology transfer obligation (Rodrik, 2007). 
from automotive sector only made 9.1 percent of Indonesia's total export, whereas in Malaysia reached 36.3 percent, Singapore 45.2 percent and the Philippines 59.6 percent (Athukorala, 2006).

The problem does not lie in policy choices. Indonesia experienced both nationalist (localcontent requirement) and liberal policies (harmonized system), but both failed to energize industrial transformation. The actual problem lies in the lack of coordination to ensure either policies to work. Let us consider the insufficient skills and technology issue. On one hand, domestic company does not have the required capacity, while on the other hand, foreign transnational company (TNC) has the technological edge. Under the localcontent requirement alone, foreign TNC would find it too costly to outsource components production to uncompetitive domestic players. Meanwhile under the Harmonized System, foreign TNC would judge the uncompetitive auto-part market not profitable enough for business expansion. It is no wonder that both policies failed. Domestic company thinks technological upgrade is too costly (although enthralled to this idea), while foreign company thinks that technological disbursement is, as well, too costly. The situation is what Rodrik (2007, 107-109) calls "coordination externalities"; each actor has its own shortcomings and its action alone cannot solve them, let alone to meet common industrialization goals. What is required here is intensive coordination to facilitate winwin situation for all parties. For example, one possible solution is for state to fill the void by conducting massive investment in human resources. As part of policy support, the state must develop a large pool of trained labors and technology-savvy domestic companies, such as by developing high-quality university, vocational school and training center.

Rattan industry shows another case where state-business coordination is lacking. Indonesia's islands of Borneo and Celebes are well-known to produce high-quality rattan, while Java (especially Cirebon city) is the center of furniture industry. So, in theory, the government, rattan farmer and furniture industrialist can work on mutuallyadvantageous cooperation. Rattan from Borneo and Celebes should be transported to Java at acceptable prices and Javanese industrialist can get stable and affordable supply of raw materials. The end-product serves mostly the international market. The government can support by providing working loan, sound logistic system, market intelligence and so on. In reality, such coordination does not exist. In 2005, the Ministry of Trade launched Decree No. 12/ 2005 to open raw rattan export to China and Vietnam. As a result, 43 percent of 220 furniture companies went bankrupt due to the lack of raw material supply (Kompas, 24 May 2010). Interestingly, the government changed the policy through the Decree of Ministry of Trade No. 36/ 2009 which banned raw rattan export. This time, it was the farmer to get jeopardizing results since the already-beaten Javanese industrial center can absorb only less than 10 percent. As a result, raw rattan prices plunged from Rp 3,500 to Rp 1,500 per kg (Kompas, 24 May 2010).

Consultative state-business relation is also lacking due to number of reasons. Indonesia has the WTO Forum which gathers various government agencies, business, academics and civil society organizations (CSOs). However, representation is a real challenge since only a handful of stakeholders are invited. There are only the Third World Network (TWN) and the Institute for Global Justice to represent CSOs and the Indonesian Chambers of Commerce and Industry (Kadin) and the Indonesian Entrepreneurs Association (APINDO) to represent domestic businesses (Chandra and Hanim, 2010, 138-139). Another supposedly coordination forum, such as the National Team on International Trade Negotiation, only works on ad-hoc and informal basis and suffers lack of authority (Chandra and Hanim, 2010, 134). Even among the state's official, coordination is always a big issue. Decentralization in the post-New Order Indonesia has given the authority for local government to impose its own policy; even at the expense of national investment practice. In 2010, the Ministry of Finance recommended to abolish 
more than 3,000 Perda (Local Decree) since it complicated business procedures (Kompas, 14 July 2010).

On top of the problem, Indonesia's state-business channel is hampered by corporatist structure within the domestic business. As argued by Rüland (2016), corporatist structure is a legacy from Suharto's authoritarian regime in which the state co-opted and manipulated interest articulation and representation from civil society organizations, including business association. On the case of ASEAN Economic Community (AEC), the government only picked a handful of business associations to consult to, which mostly consisting of big industries capable of competing at regional level, while importcompeting industries like the small and medium enterprises (SMEs) are forced to accept whatever decision the government takes (Rüland, 2016). Indonesian SMEs are also not capable of long-term planning and policy evaluation (Rüland, 2016). Therefore, business association in Indonesia is far from cohesive.

Moreover, in the era of democratizing Indonesia, industrial transformation never gets sufficient attention in national debate. During local and national election, the topic is hardly discussed. Economic issue is definitely important, but as seen in national election 2004 and 2009, it was only macroeconomic issues, such as economic growth and poverty level (Rock, 2012), rather than industrialization, that took the center spot. Even more worrying is the recent trend in Indonesia's election where identity politics becomes a heated debate. Jakarta's gubernatorial election 2016-2017 shows how religious and ethnic affinities are exploited to gain votes. For Wilson (2017), even an urgent issue such as economic inequality, which should be addressed by adequate discussion on economic and industrial policy, is framed and repackaged in identity politics. As a result, discussion, let alone consensus, on industrial transformation in Indonesia is marginalized from public scrutiny.

\section{Limited Capacity of State's Administration}

Limited capacity of Indonesian bureaucrat is a well-known subject. Indonesia maintains a poor record on bureaucratic performance as compare to regional states. The Political and Economic Risk Consultancy (PERC) launched a study to compare bureaucratic score; Indonesia performed poorly at nearly the bottom of the study (score 8.16) and was worse than Malaysia (6.3), India (6.76), and even the Philippines (7.80) and Vietnam (7.91) (PERC, 2006 as cited in Basri, 2009, 244). Indonesia's bureaucracy also shows poor sign of planning and implementing capacity, as seen from the development in copper and automotive industry.

In copper industry, Indonesia does not really have a sound planning. The country actually wishes to leave behind its post-colonial status as exporter of raw material and to infuse more added values to its export products. To serve such objectives, the government and the parliament launched the Law No. 4/ 2009 on Minerals and Coals, which banned foreign companies to export raw materials (5 years since inception), regulated them to build smelter and to divest their stocks to domestic players. These objectives are okay; the worrying issue is the inverted policy sequences that the state took. Export banning, smelter construction and stock divestment are only policy instruments. These policies have no higher standing than other instruments such as tax breaks or incentives, loan support and infrastructure development. It is interesting to observe that such particularities exceed the grand design of industrial development itself. Although the Law on Mining and Coals was launched in 2009, it was only in 2015 the state launched the Master Plan on National Industrial Development 2015-2035 (known domestically as RIPIN or Rencana Induk Pengembangan Industri Nasional). RIPIN was made as a consequence of Law No. 3 on Industry, which was also launched in 2014. Logically speaking, grand design policies like the RIPIN and Law on Industry should 
come earlier, while particular policies manifested in the Law on Mining and Coals should come next. Grand design is important to specify policy objectives, vision and mission, consensus among stakeholders, blueprint and needed particular supports. The grand design should specify what should be attained, at measureable result and at a given timeline, from export banning, smelter construction, divestment and so on. Such logical and sequential policy planning is missing in Indonesian case. Even more ironically, as RIPIN covers only general issues, a more tangible planning document is still absent, specifically in metal (or copper) industry. In October 2016, there was a call from an Indonesian parliamentary member for the government to design a roadmap for steel and metal industrial development (beritasatu.com, 2016).

Meanwhile, automotive sector shows how the state lacks implementing function. As mentioned above, Indonesian auto-parts industry seriously lacks technological and human resources capacity. However, there was an important solution through the signing of IJEPA with Japanese government in 2007. IJEPA contains a chapter on Manufacturing Industrial Development Center (MIDEC), which basically provides capacity development, human resources and technological upgrades from Japanese to Indonesian companies and workers. They are carried out through technical assistance, training and workshop on priority sectors, namely automotive, electrical and electronics, energy and heavy equipment. However in reality, Indonesian state fails to appreciate the importance of such cooperation. Between 2008 and 2013, MIDEC only carried out 24 projects and only 3 of them were in automotive sectors (Ministry of Industry, 2015). Moreover, these projects had no monitoring and evaluation mechanism, were only attended by a handful of companies and workers, were limited in Greater Jakarta area, and the substance of which had no specific correlation to export competitiveness (Hadi and Darmastuti, 2011; Ministry of Industry, 2015). The MIDEC case shows how the Indonesian state lacks implementing capacity. Moreover, it shows how the state is not able to take benefit from globalization process like the IJEPA. MIDEC Chapter in IJEPA is a result of negotiated industrial policy space between Japan and Indonesia. Such opportunity should be met by sufficient domestic policy to foster industrial transformation. Indonesian state should take advantage by inviting higher number of projects and participants, distributing assistance to local industrial centers, arranging more socialization and imposing a performance-based monitoring and evaluation.

Meanwhile, administrative state in Indonesia suffers a deeper problem. State in Southeast Asia in general and in Indonesia in particular, is neither embedded nor autonomous to the society (Jomo, 2001). ${ }^{6}$ When Suharto established the New Order, he must negotiate his tenure with existing powerful elites, namely the military, ethnic Chinese entrepreneurs and a handful of native businessmen. It created a patron-client structure where Suharto gathered political supports from all elites in exchange for protection and economic concession. As a result, oligarchs emerged around the state and a high degree of certainty was created with President Suharto as the center (Winters, 2012). In the post-New Order era, such oligarchs have showed resilience in adapting to democratization and decentralization. Various coalitions are made between state apparatus and oligarchs, from national to local level, which are usually seen as money politics during election and state projects concession (as payback) after the election (Hadiz, 2012). The lack of meaningful law and absence of strong, centralized authority like Suharto have made state-business relations in the post-New Order Indonesia more unpredictable and untamed (Winters, 2012). Even more worryingly, given its mighty financial power, the current democratic setting has swung the power pendulum to business, resulting in stronger oligarchs and weaker state (Chua, 2008). Thus, state intervention in Indonesia, be it in New Order and Post-New Order era, only serves regime survival and elite's short-term interests, rather than developmental function (Jomo, 2001). State intervention is neither intended to nurture international

\footnotetext{
${ }^{6}$ Singapore is the only exception.
} 
competitiveness nor to provide performance-based supports to domestic entrepreneurs (Jomo, 2001).

Copper industry provides another good case study. An important player here is PT Freeport Indonesia, a rich TNC from the United States (US). Suharto skillfully connected this foreign capital to his domestic cronies, namely by distributing Freeport's lucrative mining and non-mining-related concession as a means to consolidate his regime. It is no wonder that when Freeport divested 9 percent of its share in the early 1990s, it was Bakrie Brothers, one of Suharto's powerful ally, who got the share (Leith, 2002, 78). Another crony, Abdul Latif, got Freeport's housing and shopping complex in Tembagapura whereas Suharto's son Bambang Triatmojo received cargo ship contracts and Tommy Suharto got power projects (Leith, 2002, 82-83). The situation has not changed much in the Post-New Order era. Given the mandatory state's law to divest share of foreign mining company, there was a case in November 2015 where an oligarch, namely Setya Novanto who happened to be Indonesia's head of parliament, secretly requested some percentage shares to Freeport's President Director Sjafrie Sjamsoeddin (merdeka.com, 17 Dec. 2015). The scandal made Novanto withdrew from his position as head of parliament.7 The case of Freeport shows that distributional politics and rentseeking behavior are very much rampant in Indonesia. Concession and supports are given based on political connection, rather than meritocratic appointment to facilitate industrial transformation. Without proper control, Indonesia risks becoming an Africanstyle patrimonial state where business elites fully manipulate state's developmental objectives.

\section{Conclusion}

Industrial policy remains relevant in the globalization era. Considering international arena, there are two key recommendations this paper proposed, both related to policy space. First, developing country must identify loopholes available on various global governances, such as the WTO, FTAs and other regimes. There are still plenty rooms to maneuver if a developing country wishes to industrialize. A developing country can utilize market-conforming and development-related (but WTO and FTA-consistent) supports, such as subsidy for R\&D and underdeveloped local areas. Second, developing countries must negotiate policy space. There are ample evidences where these countries' FTA with developed countries result in tariff compromise, longer transition period, technical assistance and other policies necessary for infant industry development. Therefore, as articulated by Rodrik (2007), the key to industrial transformation is "the willingness to adopt it, not the ability to do so".

Given such international opportunities, one must look at the domestic aspect to understand Indonesia's deindustrialization in the post-New Order era. It is clear that the country lacks necessary domestic institutions to sustain industrial transformation. Industrial stagnation is the result of insufficient coordination between state and business and weak capacity of administrative state. One part of the problem is managerial: there are only limited and unrepresentative communication channels between state, and capital (both foreign and domestic) as well as weak technocratic capacity from the state (planning and implementation function). The other part of the problem is political: relations between state and society are not conducive for industrial transformation. Corporatist business association, rampant clientelism, and 'not embedded, not autonomy' state structure have overshadowed long-term vision of industrial transformation. Each actor is occupied with short-term interests: state officials with winning election, domestic

\footnotetext{
7 However, Novanto resumed his position in late November 2016
} 
capital with rent-seeking behavior, and foreign capital with labor-intensive, low technology industrial activity.

The third recommendation from this paper refers to the need for the country to invest in domestic institutions. Rodrik (2007) provides many useful insights for this purpose. Institutionalizing state-business relations, through more intensive and more frequent meetings, consultation and coordination, is prerequisite to determine which sectors have the best chance for success, which policy supports needed and what role should state and business play. State's support should be given based on performance, rather than political affiliation, and accompanied by sound criteria for success/ failure and intensive monitoring. Moreover, as it is difficult to expect competence of all government agencies, the government should delegate industrial transformation task to selected capable agencies and provide them with political support and high-profile status. Such approach will bring industrial sector as a national concern, rather than a mere ministerial business-as-usual task. Moreover, to reduce covert rent-seeking practices, there should be adequate transparency and public scrutiny to the agreed industrial planning, along with involvement of the Corruption Eradication Commission in industrial sector. Investing in domestic institution is clearly a long and winding road. However, all industrialized countries achieved their current status through decades-long hard works and institutional investment. Investing now, Indonesia will reap the fruit of industrial upgrading in the future.

\section{References}

\section{Books and Chapter in Book}

Basri, Faisal, 2009. Catatan Satu Dekade Krisis. Jakarta: Erlangga.

Chandra, Alexander C. and Lutfiyah Hanim, 2010. "Indonesia", in Ann Capling and Patrick Low (eds.), 2007. Governments, Non-State Actors and Trade Policy-Making: Negotiating Preferentially or Multilaterally? Cambridge: Cambridge University Press.

Chua, Christian, 2008. Chinese Big Business in Indonesia: The State of Capital. London \& New York: Routledge.

Hadiz, Vedi. R., 2012. "Democracy and Money Politics: The Case of Indonesia", in Richard Robison (ed.), 2007. Routledge Handbook of Southeast Asian Politics. Oxon, UK \& New York: Routledge.

Held, David, et.al., 1999. Global Transformation: Politics, Economics and Culture. Cambridge: Polity Press.

Johnson, Chalmers, 1982. MITI and the Japanese Miracle: The Growth of Industrial Policy, 1925-1975. Standford: Standford University Press.

Jomo, K.S., 2001. "Introduction: Growth and Structural Change in the Second-Tier Southeast Asian NICs", in K.S. Jomo (ed.), 2001. Southeast Asia's Industrialization: Industrial Policy, Capabilities and Sustainability. Basingstoke, UK and New York: Palgrave Macmillan.

Nesadurai, Helen E. S., 2003. Globalisation, Domestic Politics and Regionalism: The ASEAN Free Trade Area. London and New York: Routledge.

Noland, Marcus and Howard Pack, 2003. Industrial Policy in an Era of Globalization: Lessons from Asia. Washington DC: Institute for International Economics.

Rodrik, Dani, 2007. One Economics Many Recipes: Globalization, Institutions and Economic Growth. Princeton and Oxford: Princeton University Press. 
Solis, Mireya, 2009. “Japan's Competitive FTA strategy: Commercial Opportunity versus Political Rivalry", in Mireya Solis, Barbara Stallings and Saori N. Katada (eds.), 2009. Competitive Regionalism: FTA Diffusion in the Pacific Rim. New York and Basingstoke, UK: Palgrave Macmillan.

Thee, Kian Wee, 2012. Indonesia's Economy since Independence. Singapore: ISEAS.

Wade, Robert, 1990. Governing the Market: Economic Theory and the Role of Government in East Asian Industrialization. New Jersey: Princeton University Press.

Weiss, Linda, 1998. The Myth of the Powerless State: Governing the Economy in a Global Era. Cambridge, UK: Polity Press.

Winters, Jeffrey A., 2012. "Oligarchs and Oligarchy in Southeast Asia", in Richard Robison (ed.), 2012.. Routledge handbook of Southeast Asian Politics. Oxon, UK \& New York: Routledge.

Yamashita, Nobuaki, 2015. "Production Network Trade of ASEAN in the Context of China's Rise”, in Christopher Findlay (ed.), 2015. ASEAN and Regional Free Trade Agreements. London and New York: Routledge and ERIA.

\section{Journals and Online Journal}

Athukorala, Prema-Chandra, 2006. "Post-Crisis Export Performance: The Indonesian Experience in Regional Perspective", Bulletin of Indonesian Economic Studies, 42 (2): 177-211.

Dent, Christopher, 2003. "Transnational Capital, the State and Foreign Economic Policy: Singapore, South Korea and Taiwan”, Review of International Political Economy, 10 (2): 246-277.

Leith, Denise, 2002. "Freeport and the Suharto Regime, 1965-1998". Contemporary Pacific, 14 (1): 69-100.

Rock, Michael T., 2013. "East Asia's Democratic Developmental States and Economic Growth". Journal of East Asian Studies, 13: 1-34.

Rüland, Jürgen, 2016. "Why (Most) Indonesian Businesses Fear the ASEAN Economic Community: Struggling with Southeast Asia's Regional Corporatism”. Third World Quarterly, 1-16. Doi: 10.1080/01436597.2015.1133245.

\section{Research Reports}

Hadi, Syamsul and Shanti Darmastuti, 2011. "Implementasi Kerja Sama Ekonomi Indonesia-Jepang (IJEPA) 2008-2011: Analisis dan Evaluasi di Bidang Pembangunan Kapasitas, Ketenagakerjaan dan Government Procurement" ["The Implementation of Indonesia-Japan Economic Partnership (IJEPA) 2008-2011: Analysis and Evaluation on Capacity Development, Manpower and Government Procurement"]. Unpublished Research Report from the National Development Planning Agency (Bappenas).

\section{Working Paper}

Molnar, Margit and Molly Lesher, 2008. "Recovery and Beyond: Enhancing Competitiveness to Realise Indonesia's Trade Potential", OECD Trade Policy Working Paper No. 82. http://www.oecd-ilibrary.org/trade/recovery-and-beyond-enhancingcompetitiveness-to-realise-indonesia-s-trade-potential_227205773037

\section{Official Publication}

Ministry of Industry, 2015. "MIDEC: New Initiative Approach". http://apki.net/wpcontent/uploads/2015/o7/New-MIDEC.pdf 


\section{Newspapers}

Kompas, 2010. "Industri Rotan Mati Suri" ["Rattan Industry in Dead Faint”]. Kompas Daily Newspaper, 24 May.

Kompas, 2010. "Perda Perburuk Iklim Investasi" ["Local Decree Worsens Investment Climate"]. Kompas Daily Newspaper, 14 July.

\section{Online Articles}

Beritasatu.com, n.d. "Hentikan Deindustrialisasi" ["Stop Deindustrialization"]. http://www.beritasatu.com/blog/tajuk/4850-hentikan-deindustrialisasi.html, accessed 12 June 2017.

Beritasatu.com, 14 October 2016. "Pemerintah Diminta Siapkan Peta Jalan Industri Logam" ["Government is asked to Prepare Roadmap for Metal Industry"]. http://www.beritasatu.com/industri-perdagangan/392754-pemerintah-dimintasiapkan-peta-jalan-industri-logam.html, accessed 30 May 2017.

Merdeka.com, 17 December 2015. "Kronologi Lengkap Kasus Papa Minta Saham Sampai Bikin Setnov Mundur" ["Full Chronology on the Case of 'Papa Requested Stocks' until Setnov Withdrew"]. https://www.merdeka.com/peristiwa/kronologis-lengkap-kasuspapa-minta-saham-sampai-bikin-setnov-mundur.html accessed 10 June 2017.

Sindonews.com, 20 September 2016, "Kadin Sebut Indonesia Alami Gejala Deindustrialisasi" ["Kadin Said Indonesia Suffered Symtimps of Deindustrialization"]. https://ekbis.sindonews.com/read/1140692/34/kadin-sebut-indonesia-alami-gejaladeindustrialisasi-1474342240, accessed 30 May 2017.

Wilson, Ian, 2017. "Jakarta: Inequality and the Poverty of Elite Pluralism". http://www.newmandala.org/jakarta-inequality-poverty-elite-pluralism/, accessed 16 May 2017. 